\title{
KLASIFIKASI KEHAMILAN BERESIKO DENGAN MENGGUNAKAN METODE K-NEAREST NEIGHBOR (STUDI KASUS DINAS KESEHATAN KABUPATEN MALANG)
}

\author{
Diina Itsna Annisa ${ }^{1}$, Rudy Ariyanto ${ }^{2}$, Ariadi Tri Retno Hayati Ririd ${ }^{3}$ \\ Program Studi Teknik Informatika, Jurusan Teknologi Informasi, Politeknik Negeri Malang \\ Jl. Soekarno-Hatta No.9 Malang 65141, Indonesia \\ 1.diinaitsnaannisa@gmail.com, ${ }^{2}$ ariyantorudy@gmail.com, ${ }^{3}$ faniri4education@ gmail.com
}

\begin{abstract}
Abstrak
Masing-masing kehamilan pasti memiliki resiko yang berbeda-beda. Di Kabupaten Malang tingkat kehamilan berisiko ditargetkan hanya $20 \%$ dari total ibu hamil yang ada pada masing-masing wilayah, akan tetapi angka yang ditargetkan tidak selalu sesuai dengan hasil yang ada di lapangan. Di wilayah kerja Dinas Kesehatan Kabupaten Malang tepatnya di bagian selatan, keberadaan dokter spesialis kandungan sangatlah minim sehingga pemeriksaan kehamilan hanya sebatas di puskesmas maupun bidan praktek mandiri saja. Dengan kondisi seperti itu, jika terjadi permasalahan terhadap kondisi kehamilan seseorang akan memerlukan waktu untuk berkonsultasi terhadap dokter yang ada di pusat kota. Dalam penelitian ini akan membahas mengenai klasifikasi kehamilan beresiko dengan menggunakan metode K-Nearest Neighbor, dengan adanya klasifikasi ini diharapkan mampu mendeteksi sejak dini dan mengurangi angka kematian ibu, janin dan bayi akibat kehamilan beresiko. Hasil uji dalam mengukur akurasi metode ini menggunakan metode validasi dengan membandingkan data yang diperoleh dari dinas kesehatan (puskesmas) dengan sistem dan menghasilkan tingkat akurasi nilai sebesar $93 \%$ dengan menggunakan nilai $\mathrm{K}=5$, maka metode ini dapat dikategorikan baik dalam mengklasifikasi kehamilan beresiko ini.
\end{abstract}

Kata kunci : Kehamilan Beresiko, Dinas Kesehatan Kabupaten Malang, K-Nearest Neighbor

\section{Pendahuluan}

Kehamilan beresiko merupakan suatu kehamilan yang memiliki resiko lebih besar dari biasanya (baik dari ibu maupun bayinya). Kehamilan beresiko ini menyebabkan terjadinya bahaya dan komplikasi yang lebih besar terhadap ibu atau janin selama kehamilan, persalinan maupun nifas jika dibandingkan dengan kehamilan, persalinan dan nifas normal.

Banyaknya kasus kehamilan beresiko di Kabupaten Malang (wilayah selatan), berakibat juga terhadap banyaknya angka kematian ibu dan anak. Dengan tingginya jumlah kehamilan beresiko menjadikan tugas tersendiri bagi para tenaga kesehatan di kabupaten Malang. Dalam targetnya hanya $20 \%$ dari jumlah ibu hamil yang ada di wilayah kabupaten Malang yang mengalami kehamilan beresiko. Akan tetapi kenyataan di lapangan tidak sesuai dengan data yang telah di targetkan, bisa lebih banyak atau bahkan juga bisa kurang dengan target yang ditetapkan.

Terbatasnya jumlah dokter kandungan yang berada di Dinas Kesehatan Kabupaten Malang, dan banyaknya jumlah penduduk di Kabupaten Malang menjadikan kesehatan Ibu dan Anak di Kabupaten Malang tersebut hanya di layani oleh bidan - bidan yang ada di masing-masing wilayah kerja Dinas Kesehatan Kabupaten Malang. Permasalahan kehamilan beresiko yang terjadi di wilayah tersebut menyebabkan konsultasi kehamilan beresiko dilakukan kepada dokter kandungan yang berada di pusat pemerintahan.

Dengan adanya permasalahan di atas penulis mencoba untuk mengklasifikasikan kehamilan ibu, apakah ibu tersebut akan masuk kedalam Kelompok 1, Kelompok 2, atau Kelompok 3 dan pada masa kehamilan resiko yang terjadi dalam penelitian ini diklasifikasikan menjadi dua yaitu pendarahan dan eklampsia. Sesuai dengan kriteria yang ada, akan di klasifikasikan menggunakan metode K-Nearest Neighbor berdasarkan data sample ibu hamil yang telah mengalami kehamilan beresiko. Sehingga setelah proses klasifikasi tersebut diharapkan kehamilan tersebut dapat di awasi, jika di butuhkan akan diberikan rujukan untuk perawatan lebih lanjut sehingga dapat meminimalisir kematian ibu dan anak. 


\section{Tinjauan Teori}

\subsection{Kehamilan Beresiko}

Kehamilan beresiko adalah kehamilan yang memiliki resiko meninggalnya bayi, ibu atau melahirkan bayi yang cacat atau terjadi komplikasi kehamilan, yang lebih besar dari resiko pada wanita normal umumnya. Penyebab kehamilan risiko pada ibu hamil adalah karena kurangnya pengetahuan ibu tentang kesehatan reproduksi, rendahnya status sosial ekonomi dan pendidikan yang rendah. Pengetahuan ibu tentang tujuan atau manfaat pemeriksaan kehamilan dapat memotivasinya untuk memeriksakan kehamilan secara rutin.

Risiko adalah suatu ukuran statistik dari peluang atau kemungkinan untuk terjadinya suatu keadaan gawat-darurat yang tidak diinginkan pada masa mendatang, yaitu kemungkinan terjadi komplikasi obstetrik pada saat persalinan yang dapat menyebabkan kematian, kesakitan, kecacatan, atau ketidak puasan pada ibu atau bayi (Poedji Rochjati, 2003: 26).

\subsection{Konsep Metode K-Nearest Neighbor}

Algoritma K-Nearest Neighbor bekerja berdasarkan jarak minimal dari query instance kepada data training dalam menentukan atau menetapkan K-Nearest Neighbor. Untuk mengumpulkan K-Nearest Neighbor dilakukan dengan mengambil mayoritas sample dari KNearest Neighbor yang akan dijadikan sebagai prediksi pada query instance

Selanjutnya dalam menemukan $\mathrm{K}$ nearest neighbor. Disini disertakan contoh pelatihan sebagai nearest neighbor jika jarak sampel pelatihan ini untuk contoh permintaan adalah kurang dari atau sama dengan jarak terkecil K-th. Dengan kata lain, kita semacam jarak semua sampel pelatihan untuk contoh permintaan dan menentukan jarak minimum K-th.

Berikut adalah langkah dalam melakukan perhitungan Algoritma K-Nearst Neighbor (Teknomo Kardi, 2012):

a. Menentukan parameter $\mathrm{K}=$ jumlah nerest neighbor

b. Menghitung kuadrat jarak antara queryinstance dan semua sample training

$$
d_{i}=\sqrt{\sum_{i=1}^{p}\left(X_{2 i}-X_{1 i}\right)^{2}}
$$

Keterangan :

$\mathrm{X}_{1}=$ Sample Data

$\mathrm{X}_{2}=$ Data Uji/Training

$\mathrm{i}=$ Variabel Data

$\mathrm{d}=$ Jarak

$\mathrm{p}=$ Dimensi data c. Mengurutkan jarak dan menentukan nearest neighbor berdasarkan jarak minimum K-th

d. Mengumpulkan kategori $\mathrm{Y}$ dari nearest neighbor

e. Menggunakan mayoritas sederhana dari kategori nearest neighbor sebagai nilai prediksi query instance

\section{Perancangan dan Implementasi}

\subsection{Perancangan Sistem}

Dalam perancangan sistem ini terdiri dari data flow diagram (DFD), flowchart dan perhitungan metode K-Nearest Neighbor

\subsubsection{Flowchart Perhitungan K-Nearest Neighbor}

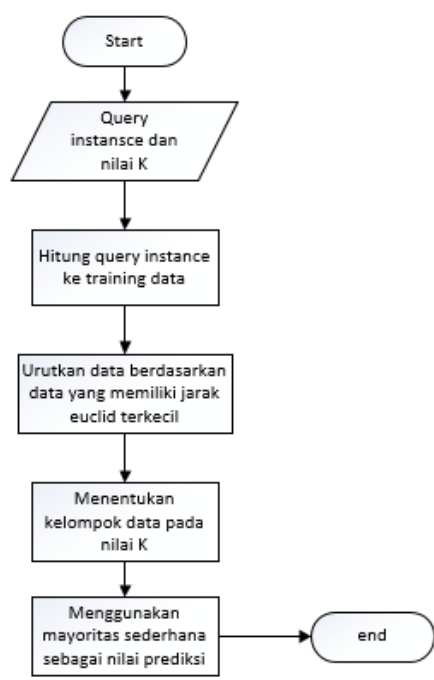

Gambar 3.1 Flowchart Perhitungan KNearest Neighbor

3.1.2 Entity Relationship Diagram

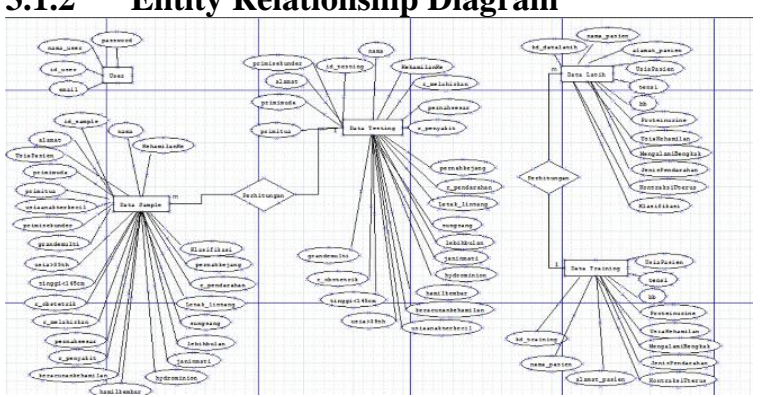

Gambar 3.2 Entity Relationship Diagram (ERD)

Dalam gambar 3.2 diatas rancangan entity relationship diagram dengan menggunakan 5 tabel yaitu tabel user, tabel data sample, dabel data testing, tabel data latih, dan tabel data training. 


\subsubsection{Data Flow Diagram (DFD)}

Data Flow Diagram merupakan gambaran suatu sistem yang telah ada atau sistem baru yang dikembangkan secara logika tanpa mempertimbangkan lingkungan fisik dimana data tersebut mengalir

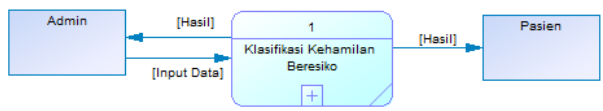

\section{Gambar 3.3 Data Flow Diagram (DFD)}

\subsubsection{Kriteria}

Dalam penelitian ini kriteria yang digunakan untuk mengklasifikasi kehamilan beresiko dengan hasil klasifikasi pendarahan dan eklampsia adalah sebagai berikut :

a. Tekanan Darah

b. Berat badan

c. Hasil Protein Urine (Positif atau Negatif)

d. Usia Kehamilan

e. Pemeriksaan Kondisi Fisik (Mengalami Bengkak)

f. Jenis Pendarahan

g. Kontraksi Uterus

Berdasarkan beberapa kriteria yang telah disebutkan di atas maka hasil dari pemeriksaan dalam penentuan klasifikasi akan di tampilkan dalam gambarberikut:

Gambar 3.4 Hasil Pemeriksaan

\begin{tabular}{|l|l|c|c|}
\hline No & \multicolumn{1}{|c|}{ Kriteria } & $\begin{array}{c}\text { Klasifikasi l } \\
\text { Pendarahan }\end{array}$ & $\begin{array}{c}\text { Klasifikasi 2 } \\
\text { Hipertensi, } \\
\text { Preeklampsia/eklampsia }\end{array}$ \\
\hline 1 & Tekanan Darah & $\sqrt{ }$ & $\sqrt{ }$ \\
\hline 2 & Berat Badan & $\sqrt{ }$ & $\sqrt{ }$ \\
\hline 3 & Hasil Protein Urine & - & $\sqrt{ }$ \\
\hline 4 & Usia Kehamilan & $\sqrt{ }$ & $\sqrt{ }$ \\
\hline 5 & Pemeriksaan Kondisi Fisik & - & $\sqrt{ }$ \\
\hline 6 & Jenis Pendarahan & $\sqrt{ }$ & - \\
\hline 7 & Kontraksi Uterus & $\sqrt{ }$ \\
\hline
\end{tabular}

Sedangkan untuk mengklasifikasi kehamilan beresiko pada awal kehamilan dengan hasil klasifikasi Ada Potensi Gawat Obstetrik, Ada Gawat Obstetrik, dan Ada Gawat Darurat Obstetrik kriteria penilaiannya adalah sebagai berikut :

1. Usia

2. Jumlah anak

3. Jarak Kehamilan dengan pernikahan

4. Usia Anak Terkecil <2th

5. Primi Tua Sekunder

6. Tinggi Badan

7. Pernah Gagal Kehamilan

8. Pernah Melahirkan dengan

a. Tarikan tang / vakum

b. Uri Dirogoh

c. Diberi infus/ tranfusi

9. Pernah Operasi Sesar

10. Penyakit pada ibu hamil a. Kurang Darah b. Malaria

c. TBC Paru

d. Payah Jantung

e. Kencing Manis (Diabetes)

f. Penyakit Menular Seksual

11. Bengkak pada Muka dan Tungkai

12. Riwayat Darah Tinggi

13. Hamil Kembar 2 atau Lebih

14. Hamil Kembar Air (hydraminon)

15. Bayi Mati dalam Kandungan

16. Kehamilan Lebih bulan

17. Letak sungsang

18. Letak Lintang

19. Pendarahan dalam Kehamilan ini

20. Pre-eklampsia berat/ kejang-kejang

Berdasarkan kriteria yang telah ada tersebut, dalam pemeriksaan awal kehamilan seorang pasien baru didapati pada kriteria yang mana saja selanjutnya akan dilakukan proses penilaian dengan menggunakan metode K-Nearest Neighbor tersebut.

\subsection{Implementasi}

\subsubsection{Implementasi Database}

Implementasi database dibuat sesuai dengan rancangan yang telah dibuat. Dalam penelitian ini database diberi nama 0klasifikasi dengan 5 tabel antara lain, tb_user, tb_datatraining, tb_datalatih, tb_datasample, dan tb_datatesting

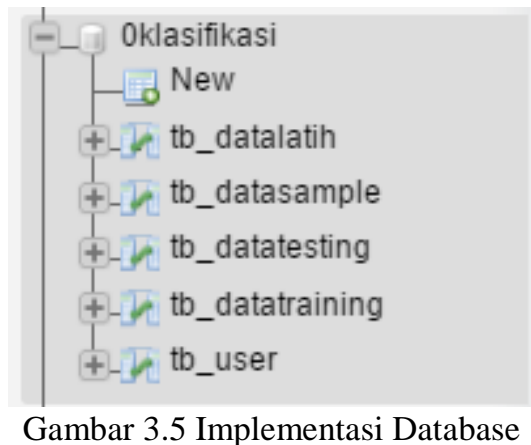

\subsubsection{Implementasi Sistem}

Implementasi Sistem merupakan implementasi dari rancangan sistem yang dibuat dengan menggunakan Code Igniter, dalam penelitian ini untuk mengklasifikasi kehamilan beresiko terdapat 3 halaman yaitu, halaman input data uji, halaman perhitungan K-Nearest Neighbor dan Halaman Hasil Klasifikasi. Adapun penerapan dalam implementasi tersebut adalah 
1. Halaman Input Data Uji

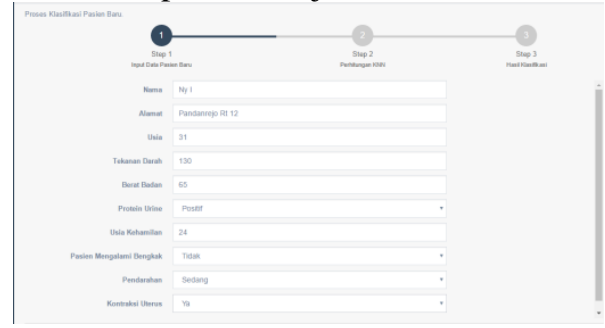

Gambar 3.6 Halaman Input Data Uji

2. Halaman Perhitungan K-Nearest Neighbor

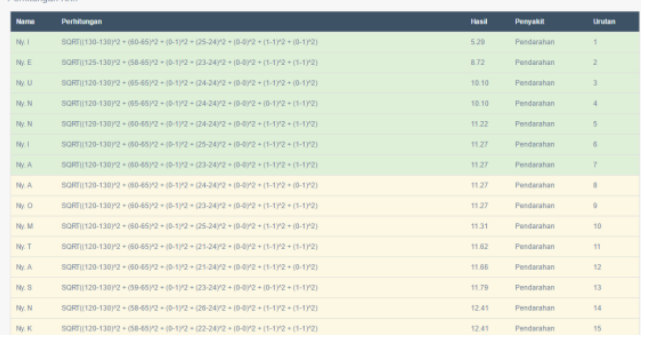

Gambar 3.7 Halaman Perhitungan K-Nearest

Neighbor

3. Halaman Hasil Klasifikasi

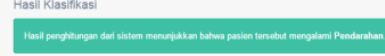

Gambar 3.8 Halaman Hasil Klasifikasi

\section{Pengujian dan Pembahasan}

\subsection{Uji Coba Perhitungan Manual}

Dalam klasifikasi kehamilan beresiko diambil 45 data sample yang akan dicari nilai nearest neighbor dengan data uji baru. Dari data sample tersebut akan dihitung nilai kedekatannya dengan menggunakan metode K-Nearest Neighbor dengan hasil sebagai berikut :

1. Menentukan parameter $\mathrm{K}=$ jumlah nerest neighbor

Nilai $\mathrm{K}$ yang digunakan dalam penelitian ini adalah 7

2. Menghitung kuadrat jarak antara queryinstance dan semua sample training

\begin{tabular}{|c|c|c|c|c|c|c|c|r|}
\hline No & Al & A2 & A3 & A4 & A5 & A6 & A7 & HP \\
\hline 1 & 110 & 63 & 0 & 23 & 0 & 1 & 0 & 20,17 \\
\hline 2 & 170 & 58 & 0 & 34 & 1 & 0 & 0 & 41,87 \\
\hline 3 & 120 & 57 & 0 & 37 & 0 & 1 & 0 & 18,30 \\
\hline 4 & 180 & 50 & 1 & 30 & 1 & 0 & 0 & 52,57 \\
\hline 5 & 175 & 60 & 0 & 35 & 2 & 0 & 0 & 46,67 \\
\hline 6 & 160 & 59 & 0 & 30 & 1 & 0 & 0 & 31,24 \\
\hline 7 & 190 & 65 & 1 & 29 & 1 & 0 & 0 & 60,23 \\
\hline 8 & 180 & 60 & 1 & 28 & 0 & 0 & 0 & 50,43 \\
\hline 9 & 120 & 58 & 0 & 26 & 0 & 1 & 1 & 12,41 \\
\hline 10 & 165 & 65 & 1 & 29 & 1 & 0 & 0 & 35,40 \\
\hline 11 & 120 & 57 & 0 & 25 & 0 & 1 & 1 & 12,88 \\
\hline 12 & 125 & 58 & 0 & 23 & 0 & 1 & 1 & 8,72 \\
\hline 13 & 120 & 60 & 0 & 21 & 0 & 1 & 1 & 11,62 \\
\hline 14 & 170 & 68 & 1 & 26 & 1 & 0 & 0 & 40,20 \\
\hline 15 & 120 & 65 & 0 & 24 & 0 & 1 & 0 & 10,10 \\
\hline 16 & 180 & 70 & 1 & 28 & 1 & 0 & 0 & 50,44 \\
\hline 17 & 120 & 60 & 0 & 25 & 0 & 1 & 1 & 11,27 \\
\hline 18 & 185 & 75 & 1 & 27 & 1 & 0 & 0 & 56,01 \\
\hline 19 & 120 & 55 & 0 & 22 & 0 & 1 & 0 & 14,35 \\
\hline 20 & 150 & 60 & 1 & 25 & 1 & 0 & 0 & 20,71 \\
\hline 21 & 170 & 70 & 0 & 25 & 1 & 0 & 0 & 40,37 \\
\hline 22 & 120 & 58 & 0 & 22 & 0 & 1 & 1 & 12,41 \\
\hline 23 & 130 & 60 & 0 & 25 & 0 & 1 & 0 & 5,29 \\
\hline 24 & 180 & 75 & 1 & 26 & 1 & 0 & 0 & 51,06 \\
\hline 25 & 120 & 60 & 0 & 24 & 0 & 1 & 0 & 11,27 \\
\hline 26 & 120 & 59 & 0 & 23 & 0 & 0 & 1 & 11,79 \\
\hline 27 & 160 & 65 & 0 & 26 & 1 & 0 & 0 & 30,13 \\
\hline 28 & 120 & 56 & 0 & 21 & 0 & 1 & 0 & 13,86 \\
\hline & & & & & & & & \\
\hline
\end{tabular}

\begin{tabular}{|l|l|l|l|l|l|l|l|l|}
\hline 29 & 170 & 75 & 1 & 30 & 1 & 0 & 0 & 41,70 \\
\hline 30 & 120 & 60 & 0 & 24 & 0 & 1 & 1 & 11,22 \\
\hline 31 & 180 & 68 & 1 & 25 & 0 & 0 & 0 & 50,12 \\
\hline 32 & 120 & 60 & 0 & 21 & 0 & 1 & 0 & 11,66 \\
\hline 33 & 160 & 60 & 1 & 25 & 1 & 0 & 0 & 30,48 \\
\hline 34 & 120 & 65 & 0 & 24 & 0 & 0 & 1 & 10,10 \\
\hline 35 & 165 & 70 & 0 & 25 & 1 & 0 & 0 & 35,43 \\
\hline 36 & 120 & 60 & 0 & 23 & 0 & 1 & 1 & 11,27 \\
\hline 37 & 160 & 60 & 1 & 23 & 0 & 0 & 0 & 30,46 \\
\hline 38 & 120 & 55 & 0 & 22 & 0 & 1 & 1 & 14,32 \\
\hline 39 & 120 & 60 & 0 & 25 & 0 & 1 & 0 & 11,31 \\
\hline 40 & 170 & 60 & 1 & 27 & 1 & 0 & 0 & 40,46 \\
\hline 41 & 120 & 54 & 0 & 21 & 0 & 1 & 1 & 15,20 \\
\hline 42 & 160 & 70 & 1 & 25 & 1 & 0 & 0 & 30,48 \\
\hline 43 & 120 & 52 & 0 & 21 & 0 & 1 & 0 & 16,73 \\
\hline 44 & 170 & 67 & 0 & 25 & 1 & 0 & 0 & 40,11 \\
\hline 45 & 120 & 60 & 0 & 23 & 0 & 1 & 1 & 11,27 \\
\hline
\end{tabular}

3. Mengurutkan jarak dan menentukan nearest neighbor berdasarkan jarak minimum K-th

\begin{tabular}{|c|c|c|c|c|c|c|c|c|}
\hline No & Al & $\mathbf{A 2}$ & $\mathbf{A 3}$ & $\mathbf{A 4}$ & $\mathbf{A 5}$ & $\mathbf{A 6}$ & $\mathbf{A 7}$ & $\mathbf{H P}$ \\
\hline 1 & 125 & 58 & 0 & 23 & 0 & 1 & 1 & 5,29 \\
\hline 2 & 120 & 65 & 0 & 24 & 0 & 1 & 0 & 8,72 \\
\hline 3 & 120 & 65 & 0 & 24 & 0 & 0 & 1 & 10,10 \\
\hline 4 & 120 & 60 & 0 & 24 & 0 & 1 & 0 & 10,10 \\
\hline 5 & 130 & 60 & 0 & 25 & 0 & 1 & 0 & 11,22 \\
\hline 6 & 120 & 60 & 0 & 24 & 0 & 1 & 1 & 11,27 \\
\hline 7 & 120 & 60 & 0 & 25 & 0 & 1 & 0 & 11,27 \\
\hline 8 & 120 & 60 & 0 & 25 & 0 & 1 & 1 & 11,27 \\
\hline 9 & 120 & 60 & 0 & 23 & 0 & 1 & 1 & 11,27 \\
\hline 10 & 120 & 60 & 0 & 23 & 0 & 1 & 1 & 11,31 \\
\hline 11 & 120 & 60 & 0 & 21 & 0 & 1 & 0 & 11,62 \\
\hline 12 & 120 & 60 & 0 & 21 & 0 & 1 & 1 & 11,66 \\
\hline 13 & 120 & 59 & 0 & 23 & 0 & 0 & 1 & 11,79 \\
\hline 14 & 120 & 58 & 0 & 26 & 0 & 1 & 1 & 12,41 \\
\hline 15 & 120 & 58 & 0 & 22 & 0 & 1 & 1 & 12,41 \\
\hline 16 & 120 & 57 & 0 & 25 & 0 & 1 & 1 & 12,88 \\
\hline 17 & 120 & 56 & 0 & 21 & 0 & 1 & 0 & 13,86 \\
\hline 18 & 120 & 55 & 0 & 22 & 0 & 1 & 0 & 14,32 \\
\hline 19 & 120 & 55 & 0 & 22 & 0 & 1 & 1 & 14,35 \\
\hline 20 & 120 & 54 & 0 & 21 & 0 & 1 & 1 & 15,20 \\
\hline
\end{tabular}




\begin{tabular}{|l|l|l|l|l|l|l|l|l|}
\hline 21 & 120 & 52 & 0 & 21 & 0 & 1 & 0 & 16,73 \\
\hline 22 & 110 & 63 & 0 & 23 & 0 & 1 & 0 & 18,30 \\
\hline 23 & 120 & 57 & 0 & 37 & 0 & 1 & 0 & 20,17 \\
\hline 24 & 150 & 60 & 1 & 25 & 1 & 0 & 0 & 20,71 \\
\hline 25 & 160 & 65 & 0 & 26 & 1 & 0 & 0 & 30,13 \\
\hline 26 & 160 & 60 & 1 & 23 & 0 & 0 & 0 & 30,46 \\
\hline 27 & 160 & 60 & 1 & 25 & 1 & 0 & 0 & 30,48 \\
\hline 28 & 160 & 70 & 1 & 25 & 1 & 0 & 0 & 30,48 \\
\hline 29 & 160 & 59 & 0 & 30 & 1 & 0 & 0 & 31,24 \\
\hline 30 & 165 & 65 & 1 & 29 & 1 & 0 & 0 & 35,40 \\
\hline 31 & 165 & 70 & 0 & 25 & 1 & 0 & 0 & 35,43 \\
\hline 32 & 170 & 60 & 1 & 27 & 1 & 0 & 0 & 40,11 \\
\hline 33 & 170 & 67 & 0 & 25 & 1 & 0 & 0 & 40,20 \\
\hline 34 & 170 & 68 & 1 & 26 & 1 & 0 & 0 & 40,37 \\
\hline 35 & 170 & 70 & 0 & 25 & 1 & 0 & 0 & 40,46 \\
\hline 36 & 170 & 58 & 0 & 34 & 1 & 0 & 0 & 41,70 \\
\hline 37 & 170 & 75 & 1 & 30 & 1 & 0 & 0 & 41,87 \\
\hline 38 & 175 & 60 & 0 & 35 & 2 & 0 & 0 & 46,67 \\
\hline 39 & 180 & 60 & 1 & 28 & 0 & 0 & 0 & 50,12 \\
\hline 40 & 180 & 68 & 1 & 25 & 0 & 0 & 0 & 50,43 \\
\hline 41 & 180 & 70 & 1 & 28 & 1 & 0 & 0 & 50,44 \\
\hline 42 & 180 & 75 & 1 & 26 & 1 & 0 & 0 & 51,06 \\
\hline 43 & 180 & 50 & 1 & 30 & 1 & 0 & 0 & 52,57 \\
\hline 44 & 185 & 75 & 1 & 27 & 1 & 0 & 0 & 56,01 \\
\hline 45 & 190 & 65 & 1 & 29 & 1 & 0 & 0 & 60,23 \\
\hline
\end{tabular}

4. Mengumpulkan kategori $\mathrm{Y}$ dari nearest neighbor

\begin{tabular}{|c|c|c|c|c|c|c|c|c|}
\hline No & Al & A2 & A3 & A4 & A5 & A6 & A7 & HP \\
\hline 1 & 125 & 58 & 0 & 23 & 0 & 1 & 1 & 5,29 \\
\hline 2 & 120 & 65 & 0 & 24 & 0 & 1 & 0 & 8,72 \\
\hline 3 & 120 & 65 & 0 & 24 & 0 & 0 & 1 & 10,10 \\
\hline 4 & 120 & 60 & 0 & 24 & 0 & 1 & 0 & 10,10 \\
\hline 5 & 130 & 60 & 0 & 25 & 0 & 1 & 0 & 11,22 \\
\hline 6 & 120 & 60 & 0 & 24 & 0 & 1 & 1 & 11,27 \\
\hline 7 & 120 & 60 & 0 & 25 & 0 & 1 & 0 & 11,27 \\
\hline
\end{tabular}

5. Menggunakan mayoritas sederhana dari kategori nearest neighbor sebagai nilai prediksi query instance

Dengan menggunakan mayoritas sederhana dari jarak minimum nilai prediksi dari data uji yang telah dilaksanakan di atas dapat di tarik kesimpulan bahwa dari 7 data tersebut merupakan 7 data dengan klasifikasi pendarahan dan 0 data dengan klasifikasi eklampsia, dengan perbandingan pendarahan 7 kali lebih besar dari eklampsia maka hasil klasifikasi terhadap data uji adalah "pendarahan".

\subsection{Pembahasan Hasil}

\begin{tabular}{|c|c|c|}
\hline Data Uji Ke & Hasil Klasifikasi Pakar & $\begin{array}{c}\text { Hasil Klasifikasi Sistem } \\
\text { Dengan Nilai K=5 }\end{array}$ \\
\hline 1 & Eklampsia & Eklampsia \\
\hline 2 & Eklampsia & Eklampsia \\
\hline 3 & Pendarahan & Pendarahan \\
\hline 4 & Pendarahan & Pendarahan \\
\hline 5 & Pendarahan & Pendarahan \\
\hline 6 & Pendarahan & Pendarahan \\
\hline 7 & Eklampsia & Eklampsia \\
\hline 8 & Pendarahan & Pendarahan \\
\hline 9 & Eklampsia & Eklampsia \\
\hline 10 & Eklampsia & Pendarahan \\
\hline 11 & Eklampsia & Eklampsia \\
\hline 12 & Pendarahan & Pendarahan \\
\hline 13 & Eklampsia & Eklampsia \\
\hline 14 & Pendarahan & Pendarahan \\
\hline 15 & Pendarahan & Pendarahan \\
\hline
\end{tabular}

Hasil Perbandingan Perhitungan Manual dengan Perhitungan Sistem dengan nilai $\mathrm{K}=5$

Pada Tabel 4.4 dilakukan perbandingn hasil klasifikasi berdasarkan pakar dengan klasifikasi yang dilakukan oleh sistem dengan menggunakan nilai $\mathrm{K}=5$. Dari hasil diatas diketahui bahwa dengan menggunakan nilai $\mathrm{K}=5$, didapatkan hasil akurasi kebenaran sebanyak $93 \%$

Dalam penelitian klasifikasi kehamilan beresiko dengan menggunakan metode $K$-Nearest Neighbor ini, untuk penentuan nilai $\mathrm{K}$ sangat mempengaruhi hasil ketepatan prediksi data uji. Untuk mengetahui nilai $\mathrm{K}$ terbaik dalam penelitian ini akan ditampilkan pada Tabel 4.5

Tabel 4.5 Pengujian Akurasi Nilai K

\begin{tabular}{|c|c|c|}
\hline No & Nilai K & Hasil Akurasi \\
\hline 1 & 1 & $80 \%$ \\
\hline 2 & 2 & $73 \%$ \\
\hline 3 & 3 & $87 \%$ \\
\hline 4 & 4 & $80 \%$ \\
\hline 5 & 5 & $93 \%$ \\
\hline 6 & 6 & $80 \%$ \\
\hline 7 & 7 & $87 \%$ \\
\hline 8 & 8 & $80 \%$ \\
\hline 9 & 9 & $87 \%$ \\
\hline 10 & 10 & $80 \%$ \\
\hline 11 & 11 & $87 \%$ \\
\hline
\end{tabular}

Berdasarkan pengujian yang telah di lakukan baik dengan pengujian secara manual maupun pengujian pada sistem dapat diketahui bahwa berdasarkan pada Tabel 6.7 hasil dari klasifikasi yang diperoleh dari pakar dengan hasil klasifikasi yang dilakukan oleh sistem dengan menggunakan nilai $\mathrm{K}=5$ memiliki tingkat akurasi sebesar $93 \%$. Hal ini disebabkan karena pada masa pengujian data yang ada antara data perhitungan manual dengan data yang ada di sistem memiliki jumlah data latih yang sama.

Berdasarkah hasil pengujian terhadap keakurasian nilai $\mathrm{K}$ yang digunakan dalam penelitian ini, dengan menggunakan nilai $\mathrm{K}=5$ mendapatkan hasil tertinggi yaitu $93 \%$. Dalam mencarian nilai $\mathrm{K}$ tidak disarankan untuk menggunakan nilai $\mathrm{K}$ dengan angka genab, karena jika menggunakan angka genab ditakutkan akan didapatkan hasil yang double. Jadi tidak bisa menghitung hasil akhir dengan menggunakan mayoritas sederhana, atau membandingkan hasil prediksi terbaik berdasarkan pengurutan hasil terkecil jarak euclidean.

\section{Kesimpulan dan Saran}

Berdasarkan penelitian yang dilaksanakan oleh penulis pada Klasifikasi Kehamilan Beresiko menggunakan metode K-Nearest Neighbor, maka dapat ditarik kesimpulan sebagai berikut :

1. Berdasarkan pengujian data rekap pasien yang dimiliki di instansi Puskesmas SumbermanjingKulon yang ada di wilayah Kabupaten Malang yang dijadikan sebagai data sample dapat dijadikan acuan untuk 
mendeteksi resiko kehamilan pada seorang pasien berdasarkan faktor resiko dan hasil pemeriksaan yang telah dilakukan terhadap pasien baru.

2. Sesuai dengan masing-masing atribut yang telah ada dengan metode K-Nearest Neighbor ini dapat dijadikan sebagai alat bantu dalam mengklasifikasi kehamilan beresiko.

3. Dalam penelitian klasifikasi dengan menggunakan metode K-nearest neighbor, penentuan nilai $\mathrm{K}$ sangat diperlukan untuk mendapatkan hasil yang maksimal. Banyaknya data sample yang dimiliki dapat menghasilkan hasil perhitungan dengan metode K-Nearest Neighbor ini lebih baik lagi.

4. Dalam menentukan nilai $\mathrm{K}$ tidak disarankan untuk menggunakan nilai $\mathrm{K}$ dengan bilangan genab karena akan didapati hasil ganda. Dalam penelitian ini setelah dilakukan uji akurasi nilai $\mathrm{K}$ yang digunakan yaitu $\mathrm{K}=5$ dengan tingkat akurasi sebesar $93 \%$.

\section{Daftar Pustaka:}

Hermawati, Fajar Astuti., 2013. Data Mining. Yogyakarta : Andi Publisher

JNPKKR-POGI., 2005. Buku Acuan Nasional Pelayanan Kesehatan Maternal dan Neonatal. Jakarta : Yayasan Bina Pustaka Sarwono Prawirohardjo.

Leidiyana, Henny., 2013. "Penerapan Algoritma KNearest Neighbor untuk Penentuan Resiko Kredit Kepemilikan Kendaraan Bermotor". Jurnal Penelitian Ilmu Komputer, System Embedded \& Logic1(1) : 65-76

Madcoms. 2009. Mengusai XHTML, CSS, PHP, \& MySQL melalui DREAMWEAVER. Yogyakarta : Penerbit Andi.

Nugroho, Bunafit. 2008. Panduan Lengkap Menguasai Perintah SQL. Jakarta : Media Kita.

Nugroho, Bunafit. 2009. Latihan Membuat Aplikasi Web PHP dan MySQL dengan Dreamweaver. Yogyakarta : Penerbit Gava Media.

Prawirohardjo, Sarwono., 2010. Ilmu Kebidanan Edisi Keempat. Jakarta : PT Bina Pustaka Sarwono Prawirohardjo

Rochijati, Poedji., 2003. Skrining Antenatal pada Ibu Hamil. Surabaya : Airlangga University Press.

Ridok, Achmad dan Muhammad Tanzil Furqon., 2010. "Pengelompokan Dokumen Berbahasa Indonesia Mengunakan Metode K-NN". Jurnal Program Studi Ilmu Komputer Universitas Brawijaya Malang.

Septian, Gugun., 2011. Trik Pintar Menguasai Code Igniter. Jakarta: Elek Media Komputindo
Suparyanto, dr. 2011. Kehamilan Normal dan Resiko Tinggi. [Online] Tersedia: http://drsuparyanto.blogspot.co.id/2011/07/kehamilannormal-dan-risiko-tinggi.html [30 November 2015]

Teknomo, Kardi., 2012. Algoritma K-Nearest Neighbor. [Online] Tersedia: http://people.revoledu.com/kardi/tutorial/KNN/ index.html. [7 Desember 2015]

Wahana Komputer. 2010. Panduan Belajar MySQL Database Server. Jakarta: Media Kita.

Yepriyanto, Rizal., et all., 2015. "Sistem Diagnosa Kesuburan Sperma Dengan Menggunakan Metode K-Nearest Neighbor (KNN)". Jurnal Ilmiah STIMIK Sinar Nusantara Surakarta. ISSN : $1693-1173$. 